\title{
Kadının Toplumsal Konumunu Siyasetnameler Üzerinden Okumak: Tipolojik Bir Yaklaşım
}

\author{
Doç. Dr. Abdullah ÖZBOLAT, Dr. Öğr. Üyesi Aslı Emine \\ $\mathrm{ÇOMU}^{\star *}$
}

Atıf / (C- Özbolat, A. ve Çomu, A. E. (2018). Kadının Toplumsal Konumunu Siyasetnameler Üzerinden Okumak: Tipolojik Bir Yaklaşım, Çukurova Üniversitesi Ilahiyat Fakültesi Dergisi, 18 (2), 1152-1179.

Öz- Sekizinci yüzyıldan itibaren, Orta Doğu ve Orta Asya'nın Müslümanlaşmış bölgelerinde yeni bir edebi tür ortaya çıkar. "Yönetici El Kitabı" veya "Hükümdar Aynası" niteliğindeki siyasetnameler, bu çalışmanın ana kaynağını oluşturan siyasi içerikli çalışmalardır. Siyasetnamelerde hükümdarların sahip olması gereken nitelikler, saltanatın koşulları ve kuralları anlatıır. Ideal bir devlet örgütünün nasıl olması gerektiği belirtilir ve kötü yönetimlerin zararlı sonuçları açıklanarak yöneticiler uyarılır. Bir ülkenin siyasal ve toplumsal yaşamını, askeri ve mali örgütlerini yasa ve tüzüklerini, toplumun gelenek ve göreneklerini de tanıtan yapıtlar olan siyasetnameler dini temellere de dayanır. Kur'an'dan, hadislerden ve tarihten de örnekler gösteren bu tür yapıtlarda, geçmişteki kötü olaylar, zalim, deneyimsiz ve cahil hükümdarların ve vezirlerin yol açtığı felaketler, öyküler ve fıkralar anlatılır. Siyasetname yazarları, çoğunlukla döneminin iyi eğitimli ve saygın kişilerdir. Siyasetname literatüründe öne çıkan siyasetnamelerin örneklem olarak ele alındığı bu çalışmada, Nizamülmülk'ün Siyasetname; Abdulhamid el Katib'in Doğunun Hükümdarı; Ebu Mansur esSealibi'nin Hükümdarlık Sanatı; Keykavus'un Kabusnâme; Yusuf Has Hacib'in Kutadgu Bilig; Muhammed b. Turtuşi'nin Siracu'l-Müluk; Ebu'l Hasan Habib elMaverdi'nin Siyaset Sanatı, Imam Gazali'nin et-Tibru'l-Mesbûk fi Nasîhati'lMülûk (Yöneticilere Altın Ögütler), Nasiruddin Tusi'nin Ahlak-ı Nasıri; İbnu'lMukaffa'nın İslam Siyaset Üslubu ve Ibn Teymiyye'nin Siyaset (es-Siyasetü'şŞeriyye) ve Narayana'nın Hitopadeşa eserleri çerçevesinde kadının toplumsal konumuna yaklaşım, "özneleşen", "nesneleşen", "temkinli” yaklaşım olmak üzere üç boyutlu olarak ele alınacaktır.

Anahtar sözcükler- Siyasetname, Yönetim, Kadının Konumu, Özne, Nesne, Toplumsal Bağlam.

\footnotetext{
* Çukurova Üniversitesi İlahiyat Fakültesi Din Sosyolojisi Anabilim Dalı e-posta: ozbolata@gmail.com, ORCID: 0000-0002-6100-4289

* Çukurova Üniversitesi İktisadi ve İdari Bilimler Fakültesi, e-posta: acomu@cu.edu.tr, ORCID: 0000-0001-9346-7475
} 


\section{$\S \S \S$}

\section{Giriş}

Arap, Fars, Hint ve Türk edebiyatlarında devlet adamlarına yöneticilik sanatına ilişkin bilgiler veren yapıtların genel adı olarak ifade edilen siyasetnameler, hükümdarlar için kaleme alınan "yönetici el kitabı" niteliğindedir. Hükümdarların sahip olması gereken nitelikler, saltanatın koşulları ve devlet yönetiminin kurallarının anlatıldığı siyasetnamelerde, ideal bir devlet örgütünün nasıl olması gerektiği belirtilir ve kötü yönetimlerin zararlı sonuçları açıklanarak yöneticiler uyarılır. Bir ülkenin siyasal ve toplumsal yaşamını, askeri ve mali örgütlerini yasa ve tüzüklerini, toplumun gelenek ve göreneklerini de tanıtan çalışmalar olarak olan siyasetnameler dini temellere de dayanır. Kur'an'dan, hadislerden ve tarihten de örnekler gösteren bu tür yapıtlarda, geçmişteki kötü olaylar, zalim, deneyimsiz ve cahil hükümdarların ve vezirlerin yol açtığı felaketler, öyküler ve fıkralar anlatılır. Siyasetnameler, bazen bizzat hükümdarın maiyetine, şehzadesine ya da halkına öğüdü şeklinde "yukarıdan aşağıya" bir öğüt kitabı niteliğinde olduğu gibi, bazen de bilge ve bilgin bir kişinin krala, hükümdara, padişaha, halifeye, hakana, kısacası yöneticiye yönelik "aşağıdan yukarıya" verdiği öğütlerdir (Hourani, 2001: 183184).

Siyasetnamelerde hükümdara öğüt niteliğinde çeşitli konularda tavsiye, telkin ve uyarılarda bulunulduğu gibi, devletin yönetimi, komutanların seçimi, ordunun savaşa hazırlanması, adalet mekanizmasının işleyişi ve elçilerin görevlendirilmesi vb. konulara yer verildiği görülmektedir. Siyasetnameler bağlamında, bu çalışmanın konusu ise, siyasetnamelerde kadın konusudur. Siyasetname literatüründen hareketle, kadının toplumsal konumunun ortaya çıkarılması amaçlanmaktadır. Kadının toplumdaki yeri ile ilgili tartışmalar, her dönemin dine, geleneklere, yerleşik düşüncelere vb. pek çok faktöre göre değerlendirdiği bir konu olması yönüyle, "tarihsel ve toplumsal" bir arkaplana sahip olduğu gibi, kadın konusunun giderek artan bir biçimde günümüz toplumlarında da çok yönlü tartışılmaya devam etmesi yönüyle "güncel ve aktüel" bir yöne de sahiptir. Sosyoloji ve din sosyolojisi literatüründe kadının toplumsal konumunun "toplumsal cinsiyet" çerçevesinde ele alındığı ve bu konuda hatırı sayılır bir literatürün oluştuğu görülmektedir ${ }^{1}$.

\footnotetext{
${ }^{1}$ Kadının konumu ve toplumsal cinsiyet literatürüne örnek olarak bakınız. (Soy, 2017; Acarlığlu, 2018; Tellioğlu, 2016; Narlı, 2000; Özdeş, 2009; Karasu, 2015; Arslan, 2014; Yalçın, 2016; Sala, 2015; Ünalan Turan, 2014; Aksu, 2001; Armaner, 1961; Teberoğlu, 2004; Yasdıman, 2005; Erkilet Başer, 1998; Çapcıoğlu, 2011; Yeter, 2015; Okudan, 2013; Dönmez, 2018; Yapıcı, 2016).
} 
Kadının toplumsal konumunun siyasetname literatürünün öne çıkan on iki örneği üzerinden ele almayı amaçlayan bu çalışma, günümüzdeki tartışmaların tarihsel köklerine giderek bir analiz, bütünlüklü bir bakış açısına ulaşılabileceği iddiasındadır. Konunun güncel ve aktüel yönünden ziyade, tarihsel boyutunu göz önünde bulundurarak, geçmişten bugüne değişimi ve dönüşümü ortaya çıkarmaktan çok, kadın konusunun "toplumsal sürekliliğine" vurgu yapılmaktadır. Bu anlamda, "kadın, nerede durmalıdır? Kadının yeri neresidir?" sorusu, kadim bir soru(n)dur. Siyasetnamelerde kadının toplumsal konumuna odaklanan bu çalışma, "sosyolojik" bir perspektiften hareket etmeyip, kadın, konusunun "tarihsel ve toplumsal düzlemdeki sürekliliklerine" odaklandığı için, kadın konusuna yönelik genel tartışmalar, toplumsal cinsiyet bağlamındaki çalışmaların verileri çalışmanın kapsamı dışında kalmaktadır. Çalışma, özelde "siyasetname literatüründe kadın" temasından hareket ettiği için, referans çerçevesi olarak siyasetnameler bağlamında kadın konusuna odaklanmıştır.

Kadının konumu, tarihsel olarak kadim bir soru(n) olarak görülmesine rağmen, kadın konusunun çok az sayıda çalışmada ele alındığı görülmektedir. Siyasetnameler üzerinden müstakil olarak yapılan çalışmalara örnek olarak, Adile Yılmaz tarafından 2004 yılında "Kutadgu Bilig'de Kadın" ve Zekiye Gizem Debreli tarafından 2016 yılında aynı başlıkla "Kutadgu Bilig'de Kadın" isimli çalışma yapılmıştır. Albayrak ve Serin tarafından, "Kutadgu Bilig ve Marifetname'de Kadın" başlıklı bir çalışma yayımlanmıştır. Bu çalışmalar incelendiğinde siyasetname literatürünün geneli yerine bir örnek üzerinden kadın konusu ele alınmıştır. Yukarıda belirtilen üç çalışmanın ortak noktası, Yusuf Has Hacib tarafından kaleme alınan Kutadgu Bilig isimli eserdir. Bu çalışmalardan hareketle, Kutadgu Bilig'e bir ilginin oluştuğu görülmekle birlikte, tek bir çalışmadan hareketle, kadının toplumsal konumuna yönelik bütünlüklü bir bakış açısına ulaşılamamaktadır.

Siyasetnamelerde ideal yönetici imgesini konu edinip, yönetici ve halkı "çoban ve kral" olarak ele alan H. Bahadır Türk (2012), ideal yöneticinin özelliklerini siyasetnameler üzerinden analiz ederken, kadının konumuna da değinir. Ona göre, kadın "ikincil” bir konumda ve toplumsal hayatta geri bir durumda bulunmaktadır. Kadının konumunun "eril bir dil" üzerinden ele alındığını ileri süren Türk'ün bakış açısına göre, kadın, yönetimden uzakta ve olabildiğince yönetimden uzak tutulması gereken bir yaklaşımla değerlendirilmektedir. Türk (2012:61-62), farklı dönemlerde, farklı 
coğrafyalarda yazılmış siyasetnamelerdeki kadın karşıtlığını toplumsal yapıdaki "eril dil"in bir uzantısı olarak görür ve kadına bakışın arka planındaki dinsel inanışlar, toplumsal-ekonomik ve kültürel yapıya uzanan bir çizgide açıklanabileceğini belirtir. Ayrıca Türk'e göre, zaman boyutunun ya da tarihsel koşulların, anlayış ve algılama biçimlerinin rolü de belirtilmeye gerek duyulmayacak kadar açıktır ancak yine de siyasetnameler ya da hükümdar aynalarında cesaretten akla, adil olmaktan cömertliğe kadar bir dizi unsurun sadece eril değerler üzerinden ele alınması, kadın karşıtı bir yaklaşım sergilenmesi ve siyasal alanın aktörleri için kadının bir tehlike olarak kodlanması anlamlıdır.

İlgili literatürde kadının ikincil konumda olduğuna yönelik görüşe karşıt olarak, kadına değer verildiğini, kadının toplumsal hayatta söz sahibi olduğunu, yönetim kademesinde de kadının hükümdarın yanında yer aldığı iddiasını öne süren araştırmacılar da bulunmaktadır. Bu yaklaşımın temsilcileri arasında Bahaeddin Ögel ve İbrahim Kafesoğlu gibi isimler bulunmaktadır. Onların yaklaşımında, "kadın" yönetim kademesine yakın, söz sahibi ve özne konumuyla ele alınmaktadır. İlk yaklaşım olarak, Ögel (2001: 251-252) ve Kafesoğlu'nun (2011: 259) yaklaşımlarına göre, Türk kültürüne ait ilk yazılı belgeler arasında gösterilen Orhun Yazıtlarında "kadın"dan saygıyla bahsedilmekte, Eski Türk devletinde kağandan sonra ikinci sırayı hatun almaktadır. Hatunların, kağanlar gibi töre ile hatunluk tahtına oturduğu ve kağan ile beraber yönetimde görev aldığı belirtilmektedir. Ayrıca savaşlarda da hatunların, kağanların yanında yer almaları; hatunların devlet meclislerine katılmaları ve oy sahibi oldukları gösterilmektedir.

Dönemler, bağlamlar farklı olmakla birlikte, bu iki yaklaşımın değerlendirilmesi ve bir analize tabi tutulması gerekmektedir. Türk-İslam kültüründe devlet geleneğine yönelik ve tarihsel-toplumsal konuların yer alması yönüyle döneminin yansıması olan siyasetnamelerin "kadın" konusuna yaklaşımın ortaya çıkarılmasına intiyaç bulunmaktadır. Bir başka ifadeyle, devlet yönetiminde kadının konumunu, siyasetnameler üzerinden değerlendirerek, Ögel ve Kafesoğlu çizgisinin ileri sürdüğü gibi, kadının konumu "olumlu, özne" bir konum mu, yoksa Türk'ün belirttiği gibi, "olumsuz, nesne" bir konum mu olduğu analiz edilmeye çalışılmaktadır.

Çalışmanın örneklemi olarak, siyasetname literatüründe öne çıkan siyasetnameler belirlenmiştir. Bu çalışmada, Nizamülmülk'ün Siyasetname; Abdulhamid el-Katib'in Doğunun Hükümdarı; Ebu Mansur es-Sealibi'nin Hükümdarlık Sanatı; Keykavus'un Kabusname; Yusuf Has Hacib'in Kutadgu Bilig; Muhammed b. Turtuşi'ninSiracu'l-Müluk; Ebu'l Hasan Habib el- 
Maverdi'nin Siyaset Sanatı, İmam Gazali'nin et-Tibru'l-Mesbûk fi Nasîhati'lMülûk (Yöneticilere Altın Ögütler), Nasiruddin Tusi, Ahlak-ı Nasıri; İbnu'lMukaffa, İslam Siyaset Üslubu; İbn Teymiyye'nin Siyaset (es-Siyasetü'şŞeriyye) ve Narayana'nın Hitopadeşa; eserleri çerçevesinde kadının toplumsal konumuna yönelik bir değerlendirme yapılacak ve belirttiğimiz siyasetnameler taranarak kadın meselesine yaklaşım ortaya konmaya çalışılmaktadır.

Yukarıda isimleri belirtilen on iki siyasetname örneğinde kadının toplumsal konumuna yönelik ifadeler, söylemler, kadına yaklaşım olarak değerlendirilmiş ve "tek" boyutlu bir değerlendirmenin "indirgemeci" olmaktan kurtulamayacaktır. Bu çalışma, siyasetname literatürünün öne çıkan örneklerine tarafsız, ideolojik eğilimleri bir kenara bırakarak bütüncül bir değerlendirme yapma iddiasından hareket ettiğinde, diğer araştırmacıların ele aldığının aksine, kadının konumunun "üç boyutlu" bir tipleştirmeyi önermektedir. Kadın konusuyla ilgili bu üçlü tipleştirme, siyasetnamelerde kadını değerli gören "iyimser", kadını nesneleştiren yaklaşım, "kötümser" ve devlet yönetiminin her alanında dikkatli olmanın telkin edildiği gibi, kadın konusunda da, "ihtiyatı" yaklaşım şeklinde kategorize edilmiştir. Bu çalışma, yöntem olarak "içerik analizi" tekniklerinden "kategorisel analizden" yararlanmıştır. Kategorisel analiz, genel olarak, belirli bir mesajın önce birimlere bölünmesini ve ardından bu birimlerin, belirli kriterlere göre kategoriler halinde gruplandırımasını ifade eder. Kategorilendirme, mesajların kodlanması, anlamlarının işlenmesi, mesajın konusu, yönü, taşıdığı değerler, amaçlar veya niyetler, amaçlara ulaşmada başvurulan yollar, mesajın tipi, biçimi, mesaj ve iletişimin özellikleri gibi boyutlar kategori oluşturmada belirleyici faktörlerdir (Bilgin, 2006: 19).

\section{a) Siyasetnamelerde Özneleşen Kadın: İyimser Yaklaşım}

Siyasetnamelerde kadın konusuyla ilgili, ilk yaklaşım, kadını değerli gören "özneleşen" kadın yaklaşımdır ve kadının toplumsal konumu, ikincil bir konumda bulunmamaktadır. Bu bakış açısında kadına daha toleransıı yaklaşılırken kadının konumu takdir edilmektedir. Siyasetnamelerdeki kadın konusuyla ilgili, "iyimser" yaklaşıma örnek olarak Keykavus ${ }^{2}$ verilebilir.

\footnotetext{
${ }^{2}$ Kısa adı Keykavus olan Emîr Unsûrü'l-meâlî Keykâvus b. İskender b. Kabûs b. Veşmgîr, Kabusname adlı eseriyle tanınan Ziyârî hükümdarıdır. Oğlu Gîlân Şah için 1082'de (h.475)'te kaleme aldığı Kabusname'yi tamamladıktan birkaç yıl sonra vefat eder. Keykâvus'un, devletin başına geçtiğinde nasıl davranacağı konusunda oğluna bilgi vermek amacıyla kaleme aldığı Kabusname, Enderznâme, Pendnâme, Kitâbü'n-Naśîhat, Naśîhatnâme isimleriyle de bilinir. Bir önsöz ve kırk dört bölümden meydana gelen eser Moğol istilâsı öncesi İslâm medeniyetinin bir özeti niteliğindeki eser, bu dönemin siyasî, içtimaî, iktisadî, ilmî, hukukî durumu, eğitim öğretim, sanat ve
} 
Kabusnamede, "eş seçmeyi bilmek ve evlilik adabını bilmek" bahsinde, "Ey oğul, gün gelip evlendiğin zaman, eşine hürmet etmekte kusur etme. Eğer bir değerli nesnen varsa, o değerli nesneyi ne olursa hanımından sakınma." (Keykavus, 2008: 98) şeklinde öğüt vermektedir. Bu bağlamda, Yusuf Has Hacib $^{3}$ de Kutadgu Bilig'te erkeğin bir kadına intiyacı olduğunu söyleyerek iyi bir eş bulmanın erkek için ne kadar önem arz ettiğini şu şekilde dile getirmektedir: "Bütün dünya zevki, şu üç şeydir; her üçünün tadı da birbirine denktir. Bu üçün biri, yemek içmektir; biri de erkeği avutan dişidir. Üçüncüsü ise esen yaşamaktır, bu üç şeyden en gerekli olanı da odur" (Yusuf Has Hacib, 2014: 315) şeklinde kadın, dünyanın güzellikleri arasında sayılmaktadır.

Imam Gazali ${ }^{4}$ ise, yöneticilere altın öğütlerinde, bir hikmet ehlinden (2014: 250) "fakirlere kibirle değil tevazu gözüyle, zenginlere haset gözüyle değil, nasihatçi gözüyle, kadınlara şehvetle değil, şefkat gözüyle bakmalısın" bir nakilde bulunur. Kadının dinine bağlı olması ve örtünmesini, Allah'ın kuluna verdiği nimetlerden kabul ederek, gerçekten dinine bağlı, iffetli bir kadına hiçbir kötü niyetli kişi yaklaşamayacağını belirten Gazali (2014: 280), hem Hakkın hem de halkın kızacağı hususlar arasında, Allah'a itaati emretmemek, din işlerini öğretmemek, onlara haram yedirmek, çalışanın ücretini vermemek, kadının mehrini vermemek gibi işleri yapanları sıralar (İmam Gazali, 2014: 78) ve akıllı olan kocaların kadınlarına merhametli olup zulüm ve haksızlık etmemesi (İmam Gazali, 2014: 288) gerektiğini belirtir.

Kadına değer veren ve belirli ölçüde dikkate alan bir yaklaşımın örneği, İbn Teymiyye ${ }^{5}$ de de görülmektedir. Kadının kocasının malında ve bedeninde

meslekleri hakkında güvenilir bir kaynaktır ve Farsça nesrin seçkin örneklerinden biri olarak görülür (Kurtuluş, 2002: 357).

${ }^{3}$ Yusuf Has Hacib, Balasagun'da soylu bir aile içinde dünyaya gelmiş, bilimi, erdemi, zühd ve takvâsı ile dikkatleri çekmiş, eserini bir buçuk yılda Balasagun'da yazıp Kâşgar'da tamamlayarak 1069-70 yılında Karahanlılar'ın hakanı Süleyman Arslan Hakan oğlu Tavgaç Uluğ Buğra Han'a sunmuştur. Şairin birikimini takdir eden hakan, kendisine "görevlerin en incesi olan" (2484. beyit) has hâciblik unvanını vermiştir (Di̇A Komisyon, 2002: 478).

${ }^{4}$ Kısa adıyla Gazzali olarak bilinen Hüccetü'l-İslâm Ebû Hâmid Muhammed b. Muhammed b. Muhammed b. Ahmed el-Gazzâlî et-Tûsî, Eş‘arî kelâmcısı, Şâfiî fakihi, mutasavvıf, filozoflara yönelttiği eleştirilerle tanınan İslâm düşünürüdür. Büyük Selçuklu Devleti devrinin İslam âlimi Gazzâlî Hicri 450 (Miladi 1058) yılında Horasan'ın Tus şehrinde doğmuştur. İlk öğrenimini Tus'ta, daha sonra Cürcan şehrine giderek eğitim görmüş, daha sonra 28 yaşına kadar Nişabur Nizamiye Medresesi'nde öğrenim görmüştür. İtikadi düşünce olarak Ebü'l Hasan Eş'arî'den ve ameli görüş olarak Şafiî'den etkilenir. 1091 yılında Bağdat’taki Nizamiye Medresesi'nin Baş Müderrisliği'ne tayin edilir. Burada bilgisi ve edindiği öğrenci topluluğuyla kısa sürede ün ve saygınlık kazanır. Sûfizm'e yönelir, medresedeki görevini bırakıp önce Şam'a, sonra Tus'a geçer. Gazzâlî 1111 (Hicri 505) yılında doğum yeri olan İran'ın Tûs şehrinde vefat eder (Çağrıcı, 1996: 489-494).

${ }^{5}$ Kısa adı İbn Teymiyye olan Ebü'l-Abbâs Takıyyüddîn Ahmed b. Abdilhalîm b. Mecdiddîn Abdisselâm el-Harrânî, görüş ve eleştirileriyle İslâm düşüncesinin gelişmesine tesir eden Selefî âlimi ve müctehiddir. İbn Teymiyye, 1263'te (h.661) Harran'da doğar. İlk eğitimine Dımaşk'ta babasının müderrislik yaptığı Sükkeriyye Dârülhadisi'nde başlayan İbn Teymiyye, başta bu 
hakkı olduğunu belirten İbn Teymiyye (1999:141-142), kocanın malındaki hakkı, mihr ve normal şekildeki nafaka; bedenindeki hakkını da, kendisiyle iyi geçim ve faydalandırma olarak sıralamaktadır. Bu yüzden kadın, kendisine yaklaşmamak üzere yemin eden kocasından ayrılmaya, icmâ ile hak kazanabilmektedir. Kitap, Sünnet ve genel prensiplere dayanarak bilginlerin çoğuna göre, erkeğin eşiyle birleşmesinin vacip olduğunu belirten İbn Teymiyye, çok oruç tuttuğunu ve namaz kıldığını görünce, Hz. Peygamber'in (s.a.v) Abdullah b. Amr'a "Eşinin de sende hakkı bulunmaktadır, zarar vermedikçe veya bir vacipten alıkoymadıkça, kocanın dilediği zaman karısından faydalanması hakkıdır; aynı şekilde kadının da buna imkân vermesi vacip hükmündedir" şeklinde bir rivayeti aktarır. Ayrıca yine bu konuda İbn Teymiyye (1999:128-129) bir başka rivayete yer verir. Ona göre, sahih bir hadiste, Hz. Peygamber (s.a.v) "Sizden birinizin eşiyle birleşmesi sadakadır" buyurunca, sahabe "Ey Allah'ın elçisi! Bizden biri şehvetini giderince, bu yüzden sevap mı kazanır?" diye sordular. Bunun üzerine Hz. Peygamber (s.a.v) "Ne dersiniz? Haram bir iş yapmış olsaydı, günah olmayacak mıydı?" deyince, "Evet" cevabını verdiler. Hz. Peygamber de "Niye haramı hesaplıyorsunuz da, helâli hesaplamıyorsunuz?" şeklinde bir rivayete yer vermektedir.

Sealibi6 ise, (1997: 209) kadınlara olumsuz yaklaşımı belirli ölçüde dengeleyecek bir yaklaşımı hükümdarın sahip olması gereken hususlarda dile getirir. Ona göre, hükümdar, a) Güveneceği ve sırrını vereceği bir vezir, b) Zor durumda kaldığı zaman sığınacağı bir kale, c) Hasımları ile karşı karşıya geldiği zaman sarılacağı sağlam bir kılıç ki hıyanetinden korkmaya, keskinliğinden emin olabilsin d) Yükte hafif pahada ağır bir hazine ki çarkıfelek ona oyun ettiğinde alıp kurtulsun e) Boylu poslu güzel tenli bir cariye ki yanına vardığında

medresenin hocaları olmak üzere bölgenin önde gelen âlimlerinden ders alır. Babasının vefatından bir yıl sonra Sükkeriyye Dârülhadisi'nde hocalığa ve Emeviyye Camii'nde tefsir dersleri vermeye başlar. Geniş halk kitleleri ve yöneticiler nezdinde etkin bir nüfuza sahip olan İbn Teymiyye'nin VIII. (XIV.) yüzyılın başlarından itibaren çeşitli dinî ve siyasî tartışmalar içine girdiği görülmektedir. Felsefe ve kelam alanında, kuvvetli delillere sahip, selef mezhebini savunan İbn Teymiyye, Yunan mantığı, Yunan ve İslam filozoflarını tenkit eder, Ehl-i Sünnet ve'l Cemaat'in görüşlerini pekiştirmek ve sağlamlaştırmak üzere İslam mezhepleriyle ilgili münakaşaları ihtiva eden çok sayıda kitap ve risale kaleme almıştır. İbn Teymiye, 1328'de (h.728) Şam'da vefat etmiştir (Koca, 1999: 391-394). ${ }^{6}$ Hicretin 350. yılında Nişabur'da doğan Ebu Mansur Abdulmelik b. Muhammed b. İsmail es-Seâlibi, zengin bir ailede dünyaya gelir. Ailesi, tilki kürkü ticaretiyle uğraştığı için Sealibi (tilki kürkü satan) ismi buradan gelir. Sealibi'nin babası Ebû Ali'nin emirlere yakın olduğu ve kürkçülük işinin prenslerin konaklarına giden yolu açmış olabileceği belirtilmektedir. Seâlibi, kendisini edebiyata ve muallimliğe verdiği için önemli miktarda varis olduğu serveti koruyamamıştır. Hocası Harizmi, Sealibi'yi, Nişabur Hükümdarlığını elinde bulunduran Ahmed b. Ali el-Mikaili'ye takdim etmiştir. Sealibi, Samani Devleti'nin hükümdarlığında en parlak günlerini yaşamıştır. Es-Sealibi, Harizmşahi Me'mun'un, Gazneli Mahmud'un oğlu Sultan Mesud'un övgüsüne layık olmuştur. Gramer, mukayeseli filoloji, şiir eleştirisi ve siyaset gibi alanlarda çok sayıda eser kaleme alan Sealibi, Hicri 429'da Nişabur'da vefat etmiştir (Topuzoğlu, 2009: 236-239). 
huzur bulsun, ruhundan kederi kovsun f) Gayet maharetli bir aşçı ki canı hiç yemek istemediğimde dahi hazırladığı yemeğin lezzeti ile iştahını kabartsın, şeklinde altı şeye sahip olmalıdır. Sayılan altı maddede kadın, hükümdarın kaçınması gereken bir konum yerine hükümdarın huzur bulacağı bir durumda konumlandırılmaktadır. Benzer bir çerçevede Turtuşi7 (2011: 430-431) kadına değer atfeden durumu Hz. Peygamber'e atıfla ele almaktadır. Bir kadınla evlenmek isteyen adama, Hz. Peygamber: "Ona iyi bak, çünkü bakış aranızdaki Âdemliği artırır, Âdemliğe en yakışan budur. Âdemlik, aradaki sevgi ve yakınlığın artması anlamına gelir".

Siyasetnamelerde hükümdar merkezli bir bakışın hâkim olduğunu belirtmemiz gerekir. Maverdi8 (2004:447) bu konuda, hükümdarın, her çocuğu kendine evlat, her büyüğü baba, her büyük kadını kendine anne, erkeklerden her akranı kardeş, her kadını da bacı bilip onlara iyilik ve cömertlik yapan kişinin âdil bir hükümdar olacağını belirtmektedir. Burada kadına arzu nesnesi gibi yaklaşmaktansa ona bir insan evladı gibi yaklaşmak ya da kadının cinsiyetini geri planda bırakarak ona insani duygularla yaklaşılmaktadır. Kadına daha insani çerçevede yaklaşan benzer örneklerden Narayana'da9 ${ }^{9}$ (2006:14), "başkasının karısını anne gibi gören, başkasının zenginliğini dünyanın çamuru gibi gören ve tüm canlıları kendisi gibi gören kişi gerçek bir bilgedir" ve "sessiz kalmak, yalan söylemekten iyidir, başkasının karısıyla birlikte olmaktansa, iktidarsız kalmak daha iyidir, kötü insanın sözlerine katlanmaktansa, ölmek daha iyidir" (Narayana, 2006: 35), ve "ana, eş, kardeş veya oğlu gibi doğal olarak dostumuz olan kişilere güven duymamak için neden yoktur" (Narayana, 2006: 48) şeklinde kadının insani yönüne işaret olarak yorumlanabilir.

\footnotetext{
${ }^{7}$ Kısa adı, Turtuşi olan Ebû Bekr Muhammed b. Velîd b. Muhammed b. Halef el-Fihrî et-Turtûşî (ö. 520/1126), Endülüslü Mâlikî fıkıh âlimi ve muhaddistir. Arapça, fıkıh, hadis, ferâiz okuyan Turtuşi, bir süre Irak, Suriye ve Mısır'ın çeşitli şehirlerinde ikamet eder, Bağdat'ta ve Basra'da ilim halkalarına katıır. Hac yolculuğuna çıkan Endülüs ulemâsının uğrak yeri İskenderiye'ye yerleşir. Turtûşî, eşinin kendisine ayırdığı evin alt katını medreseye dönüştürüp ders vermeye başlar. Öğrencilerinin sayısı artar, şöhreti Mısır'ın dışına yayılır. Turtûşî, İskenderiye'de bir taraftan öğretim faaliyetini yürütürken diğer taraftan toplumun ahlâk bakımından ıslahı için çalışır. İslâmî esaslara aykırı sosyal ve idarî uygulamaları, şehrin kadısının tasarruflarını eleştirir, yöneticileri uyarır. 1126'da (h.520) İskenderiye'de vefat eder (Kılıç, 2012: 430-431).

${ }^{8}$ Mâverdî olarak bilinen Ebü'l-Hasen Alî b. Muhammed b. Habîb el-Basrî el-Mâverdî, siyaset ve ahlâk nazariyeleriyle tanınan Şâfiî fakihidir. Basra'da 974-975'de(h.364) doğan Maverdi, babası gül suyu (mâü'l-verd) işiyle uğraştığı için Mâverdî lakabıyla tanınır. İlk fıkıh eğitimini memleketinde aldıktan sonra, Bağdat'a gider, döneminin tanınmış âlimlerinden ders alır, yetiştikten sonra ders verir. Mâverdî, Kāim-Biemrillâh tarafından diplomatik heyetlerde görevlendirilir. Siyaset sahnesinden çekildikten sonra tamamen tedrîs ve te'lif faaliyetleriyle meşgul olur, 1058'de (h.450) Bağdat'ta vefat eder (Maverdi, 2003: 180).

${ }^{9}$ Narayana'nın 14. yüzyılda kaleme aldığı Sanskrit dilinde "yararlı eğitim", "uygun öğüt", "dostça tavsiye" anlamlarına gelen Hitopadeşa, Hint edebiyatının özgün eserlerinden birisidir (Narayana, 2006: IX-XI).
} 
Tarihsel altyapı olarak, çalışma bağlamında müracaat ettiğimiz siyasetnamelerin hemen hemen hepsinin 9. ve 10. yüzyıllarda erkek egemen Müslüman toplumlarda yazıldığı göz önüne alınırsa, kadına yaklaşımın insani olması ve kadının erkeğin hayatının tamamlayıcısı olduğu fikri kadının konumunu yücelten bir durumdur. Kadın her ne kadar bu toplum yapısında geride kalsa da, bu söylemler kadının aslında vazgeçilmez bir konumunun olduğunu, toplumun devam etmesi için kadının gerekli olduğunu ve bu yüzden de kadına değer verilmesi gerektiğinin altını çizmektedir.

\section{b) Siyasetnamelerde Nesneleşen Kadın: Kötümser Yaklaşım}

Siyasetnameler üzerinden "kötümser yaklaşım"ın ilk örneği, Kutadgu Bilig'te görülmektedir. Kutadgu Bilig'de Yusuf Has Hacib; Öğdülmiş'in Odgurmış'a verdiği öğütler arasında nasıl evlenileceği ile ilgili "evlilik" konusu da yer alır. Kutadgu Bilig'te, "eğer evlenmek istersen, çok dikkatli ol ve iyi bir kız ara" diye başlayan 4475. beyitten itibaren (Yusuf Has Hacib, 2014: 387 389) iyi bir evliliğin sırları anlatıır. Bu bölümde, evlenilecek kızın "hayâ ve takva sahibi, temiz olmasına", "el değmemiş ve başka erkek yüzü görmemiş olan bir aile kızı" olmasına, "yüz güzelliğine değil, huy güzelliğine bakılmasına" yönelik öğütlerde bulunur. "Çocukların nasıl terbiye edilmesi gerektiği" ile ilgili bölümde (4504-4526 arası beyitlerde) ise "Kızı çabuk evlendir, uzun müddet evde tutma, yoksa hastalığa lüzum kalmadan, yalnız bu pişmanlık seni öldürür", "Bu kızlar doğmasa, doğarsa yaşamasa daha iyi olur", "Eğer dünyaya gelirse onun yerinin toprağın altı veya evinin mezara komşu olması daha hayırlıdır", "Kadınları her vakit evde muhafaza et; kadının içi dışı gibi olmaz", "Yabancıyı eve sokma, kadını dışarıya çıkarma; bu kadınları sokakta gören göz onların gönüllerini çeler", "Kadını evden dışarı bırakma; eğer çıkarsa doğru yoldan şaşar", "Kadının aslı ettir, eti muhafaza etmeli; gözetmezsen et kokar; bunun çaresi yoktur", "Kadına saygı göster, ne isterse ver; evinin kapısını kilitle ve eve erkek sokma", "Bunlarda öteden beri vefa yoktur; gözleri nereye bakarsa, gönülleri oraya kayar", "Nice bin kudretli ve erlerin eri erkekler kadınlar yüzünden mahvolup gitmişlerdir", "Nice al yanaklı ve yüzü sıhhatle pırıl pırıl parlayan erkekler, kadınlar yüzünden toprak olup gitmişlerdir", "Bu kadınlar binlerce namlı ve şöhretli kahramanları diri diri yere gömmüşlerdir" gibi nasihatler bulunur (Yusuf Has Hacib, 2014: 390-391). Bu yaklaşıma ek olarak, "erkek, verdiği sözden geri dönmez; sözünden dönenleri sen kadın bil" (Yusuf Has Hacib, 2014: 435); "Bilgili, sözünü dosdoğru söyleyemez oldu, kadınlardan utanma gitti, yüzlerini örtmezler" (Yusuf Has Hacib, 2014: 546) şeklinde 
kadınlar hakkında değerlendirmeler bulunmaktadır. Ayrıca esesrin başka kısımlarında ve Ay-Toldı'nın oğlu Öğdilmiş'e öğütleri arasında da "kadın ve çocuklar, erkeğin kuvvetini keser" (Yusuf Has Hacib, 2014: 316); "Kadın ile bulunmak da ancak bazı anlarda erkeklik ateşini söndürmek içindir" (Yusuf Has Hacib, 2014: 318); "Harpte korkak kimselere lüzum yoktur; korkak insanlar kadınlara benzerler" (Yusuf Has Hacib, 2014: 214); "Gelin kızların sevinçli anları zifaf geceleridir, cesur ve kahraman erkeğin iftihar edeceği zamanlar da harp günleridir" (Yusuf Has Hacib, 2014: 222); "Kadını başıboş bırakma, kapıyı kapalı tut; insana her türlü uygunsuzluk kadından gelir" (Yusuf Has Hacib, 2014: 137) vb. ifadelerden oluşan öğütlerle karşılaşılmaktadır.

Ahlak-ı Nasıri isimli çalışmasında Nasiruddin Tusîn ${ }^{10}$, kadınlara danışılmaması konusunda hükümdarı uyarır ve "kadınlar ve çocuklar gibi zayıf akıllılarla kesinlikle konuşmamasını önerir (Tusi, 2007: 301). İbnu'l-Mukaffa'11, İslam Siyaset Üslubu'nda kadına yaklaşımını, kararı ve kalıcılığı olmayan şeyleri sıralarken belirtir. Ona göre, bulut gölgesi, kötülerin dostluğu, kadınların aşkı, yalan haber ve çok malın kalıcılığından söz edilemez (İbnu'l-Mukaffa, 2004: 49). Nizamülmülk12 ise Siyasetname'sinin "Tesettür Ehline, Harem Dairesine, Padişahın İdaresi Altındakilere ve Komutanlarının Tanzimine Dairdir" başlıklı 43. faslında okuru şu uyarıyla karşılar: "Büyük zararlara yol açacağından ve padişahın haşmet ve şanına halel getireceğinden ötürü

\footnotetext{
${ }^{10}$ İranlı âlim ve filozof, Nasiruddin Tusi, 1201'de (h.597) Tûs'ta doğar. İlk eğitimini babasından alan Tûsî on beş yaşlarında iken dönemin ilim merkezlerine yolculuk yapar. Genç yaşlarından itibaren ilme olan iştiyakı Tûsî̀yi kısa zamanda üne kavuşturur, ünü, Kuhistan bölgesinin İsmâilî hâkimi kadar ulaşır. İlk dönemlerde valinin kendisine destek olmasıyla Kuhistan'da ilmî faaliyetlerini yürütmek için uygun bir ortam bulur; özellikle felsefî ve tecrübî ilimler alanında değerli eserlerinin çoğunu burada yazar. Tûsî Bağdat'a yaptığı bir seferde 1274'te (h.672) vefat eder (Şirinov, 2012: 437).

11 İbnü'l-Mukaffa olarak tanınan Ebû Muhammed (Ebû Amr) Abdullāh (Rûzbih / el-Mübârek) b. elMukaffa' (Dâdeveyh), İran asıllı mütercim, edip ve kâtiptir. Dinî, ilmî ve felsefî fikirlerin harmanlandığı zengin bir kültür merkezi olan Basra'da dönemin yönetici ve ediplerinin meclislerine devam eden İbnü'l-Mukaffa, Arap dili ve edebiyatı başta olmak üzere Fars, Hint, Yunan kültürleri hakkında geniş bilgi sahibi olur. Memuriyet hayatına babası gibi kâtiplikle başlayan İbnü'l-Mukaffa', Emevîler döneminin sonlarında Irak Valisi Ömer b. Hübeyre'nin oğulları olan Basra ve Kûfe Valisi Yezîd ile Kirman Valisi Dâvûd'un kâtipliklerini yapar. Abbâsîler döneminde Halife Mansûr'un amcalarından Basra Valisi Süleyman b. Ali'nin kâtibi iken halifeyle tanışma imkânı bulur. Ardından Kirman Valisi Îsâ b. Ali'nin hizmetine girdi ve asıl şöhretine onun döneminde (750-752) kavuşur. İbnü'l-Mukaffa' müslüman olduktan sonra fazla yaşamamış, tercih edilen görüşe göre 759 'da (h.142) Basra'da öldürülmüştür (Durmuş, 2000: 130-134).

${ }^{12}$ Kısa adı Nizâmülmülk olan Ebû Alî Kıvâmüddîn (Gıyâsüddevle, Şemsülmille) Hasen b. Alî b. İshâk et-Tûsî (ö. 485/1092), Büyük Selçuklu veziri ve Ortaçağ İslâm dünyasının en başarılı devlet adamlarındandır. Selçuklular'da bir görev unvanı olarak ortaya çıkan "atabeg" tabirinin ilk defa Nizâmülmülk'e verildiği kaydedilmektedir. Nizâmülmülk, Nizamiye Medreseleri'nin kurucusu olarak, İslâm eğitim tarihinde önemli bir yeri vardır. Sultan Melikşah, devlet yönetimiyle ilgili bir kitap yazılması için yarışma açmış ve yazılan eserler arasından Nizâmülmülk'ün 1092'de (h.485) kaleme aldığı Siyâsetnâme ödüllendirilmiştir (Özaydın, 2007: 194-196).
} 
hükümdarın astları üst yapmaması lazımdır. Bunlar özellikle ehl-i setr olup akılları bu işlere ermeyen kadınlardır. Zira bunlar nezih bir neslin devamı için vardırlar. Onların övgüye en çok yaraşanları asil ve liyakatli, örtülü ve takvalı olanlarıdır." (Nizamülmülk, 2009: 255). Kadınların üst yönetici yapılmaması konusunda, Turtuşi'nin Ebû Bekir es-Sıddık'a atıfla aktardığı rivayet dikkat çekicidir. Bu rivayette, Kisra öldüğünde haberi Resulullah'a (s.a.v) ulaştığında, Resulullah, yerine kimi tayin ettiler diye sorar. Ashab, yerine kızı Boran'ı tayin ettiler cevabını verince, Resulullah, "Idarelerini kadına teslim eden o kavim felah bulmayacaktır” şeklinde değerlendirme yapar (Turtuşi, 2011: 408). Kadınların yönetici seçilmemesine dönük, bu yaklaşım, kadın karşıtı söylemin billurlaşmış ifadesi olarak görülebilir. Yine bu çerçevede Nizamülmülk "kadın aklına uyup, ona itibar ettiği için nice meşakkat ve zahmete düşen ilk insan, Adem aleyhisselam'ı zikrederek nasihatine kanıt teşkil edecek çeşitli hikâyeleri aktarır. Keykavus'un oğlu Siyavuş'u görünce ona tutulan ve taciz etmeye çalışan Keykavus'un eşi Sudâve'nin yol açtığı trajedilerden, Büyük İskender'in bozguna uğrattığı Dârâ bin Dârâ'nın kızıyla tanıştırılmak isteyince "Erkekleri yendik; kadınlara yenilmeyelim" diyerek teklifi reddetmesine değinir (Nizamülmülk, 2009: 258).

Kadının konumuna da değindiği hikâyelerinden birinde Nizamülmülk, Beni İsrail devrinde yaşamış, 40 yıl boyunca her tür günahtan uzak durmuş ve gündüzleri oruç tutan geceleri ibadet eden insanların üç dileğinin Tanrı tarafından yerine getirildiği bu devirde Yusuf un hikâyesini anlatır. Yusuf, 40 yılı tamamladığında ne isteyeceğine karar veremeyince eşine danışır. Yusuf'un karısı, o ana kadar kimseye bahşedilmemiş bir güzelliğe kavuşmak istediğini söyler. Yusuf, Tanrı'ya karısı için dua eder ve eşi ertesi sabah "kimsenin daha güzeline şahit olmadığı bambaşka birine" dönüşür. Gün geçtikçe de güzelleşmeye devam eder ve sonunda Yusuf'u beğenmez, her şeyden şikâyet eder hale gelir. Eşinin söylenmelerine dayanamayan Yusuf, bu defa Tanrı'dan eşini bir ayıya çevirmesi için istekte bulunur. Eşi korkunç bir ayıya dönüşür. Yusuf ayıya dönüşmüş eşini evden kovar fakat bu sefer de çocuklarıyla ilgilenecek kimse kalmamıştır. En sonunda Tanrı'ya yeniden dua ederek eşini ilk haline çevirmesini ister. Böylelikle 40 yıllık günahsızlığı karşılığında elde ettiği üç hakkını kullanmış olur. Nizamülmülk, bu kıssadan şu hisseyi çıkarır. Karısıyla istişare ettiğinden dolayı bu şekilde kırk yıl heba olur ve kendilerinden sonra bu kıssa, kimsenin kadınlara danışmaması ve kadın kısmını Tanrının özünde eğri olarak yarattığının bilinmesi için cihanda dilden dile aktarılır (Nizamülmülk, 2009: 261-262). İstişare konusunda Turtuşi (2011: 239), hakimlerin istişare edilmeyecek kişileri sıralarken, "öğretmenle, çobanla, 
kadınlarla çok oturan kimseyle ve ihtiyacını gidermek için sabırsızlanan kimseyle istişare etme, onlara akıl danışma diyerek, kadınlarla istişare etmemeyi, kadınlarla çok oturup kalkan kişilerle de istişare etmeyi sakıncalı gören bir aşamaya taşımıştır.

Nizamülmülk, bu bölümde ayrıca Halife Me'mûn ve Keyhusrev'in "kadınların aklına uyarak" hareket etmemenin önemine ilişkin sözlerine yer verir; "hükümdarların kadın sözüyle hareket etmesinin memleket, ordu, hazine, ezcümle siyaset işlerine vuracağı sekteden söz eder. Nisa Suresi 34. ayette: "Erkekler, kadınların koruyup kollayıcılarıdırlar. Çünkü Allah, insanların kimini kiminden üstün kılmıştır. Bir de erkekler kendi mallarından harcamakta (ve ailenin geçimini sağlamaktadırlar. İyi kadınlar, itaatkârdırlar. Allah'ın (kendilerini) koruması sayesinde onlar da "gayb"ı korurlar. Evlilik yükümlülüklerini reddederek başkaldırdıklarını gördüğünüz kadınlara öğüt verin, onları yataklarında yalnız bırakın. (Bunlar fayda vermez de mecbur kalırsanız) onları (hafifçe) dövün. Eğer itaat ederlerse, artık onların aleyhine başka bir yol aramayın. Şüphesiz Allah, çok yücedir, çok büyüktür. Kadınlar kendilerini idare edebilseydiler erkeklere böyle bir vazife verilmezdi" sonucunu çıkarır ve "her kim kadınları kendisine hâkim kılarsa, zuhur edecek olan her hata ve yanlışlığın suçu bu müsaadeyi vermiş kişinin olacaktır" (Nizamülmülk, 2009: 263) hatırlatmasını yapar. Ayrıca "işlerinizde kadınlarla istişare ediniz; doğru yapmak için onlar işin nasıl yapılması gerektiğini söylüyorlarsa tam tersini yapınız," hadisini aktararak "eğer kadınların aklı tam olaydı, peygamber aleyhisselam onların dediklerinin aksi istikamette hareket ediniz buyurmazdı," yorumunu yapar (Nizamülmülk, 2009: 259).

Gazâlî nasihat verdiği hükümdara şöyle seslenir: "Eğer idaredeki amacın başına süslü taçlar takmak ise, bu durumda, sen kadın tabiatlı birisin demektir. Çünkü süslenmek ve güzel elbiseler içinde zevk almak kadınların işidir" (İmam Gazali, 2014: 64). "Sokrat demiştir ki, beş şey, beş şeye doymaz: Göz bakmaya, kadın erkeğe, kulak habere, ateş oduna, âlim ilime" (İmam Gazali, 2014: 244)."Kadınların en hayırlısı ve bereketlisi; güzel, doğurgan ve mehri az olandır" Hz. Ömer, "kötü kadınlardan Allah'a sığının, hayırlı olanlarına karşı da dikkatli olun" evlenmek için güzel kadın bulamayan kişi, dinine sahip çıkan bir kadınla evlensin. Dinini yaşayan bir kadın elbette daha hayırlı ve daha bereketlidir. Din olduğu zaman, mal da gelir, rızıkta bereket olur, çünkü dini yaşamayan kadının şerefi olmaz, böyle birisiyle bereket de bulunmaz. Dinin bereketi ile bütün hayırlar elde edilir" (İmam Gazali, 2014: 273)."Kadının kocasına karşı içi ve dışıyla samimi olması, çoğu bulamadığı zaman aza kanaat etmesi gerekir. Kadın, her zaman Hz. Aişe ve Hz. Fatıma'yı kendisine örnek 
almalı, onların ahlakıyla ahlâklanmalıdır ki, cennet ehlinden olabilsin" (İmam Gazali, 2014: 285). Ayrıca İmam Gazali'ye göre, (2014: 291), kimse, bilgisi ve ilgisi olmadığı konularda kadınların sözüyle hareket etmemelidir, çünkü, insanın başına gelen ne kadar bela, musibet ve meşakkat varsa çoğunlukla, kötü tabiatlı, geçimsiz ve kanaatsiz kadın yüzünden meydana gelir.

Ayrıca kadının konumuna yönelik, bir değerlendirme de İbn Teymiyye (1999: 46) ve İmam Gazali'de (2014: 44) geçer. Bu rivayette, "Yedi kimseyi Allah Teâlâ, kendi gölgesinden başka bölge olmayan (kıyamet) gününde, kendi gölgesi altında barındıracaktır: 1) adaletli imam, 2) Rabbine (taat ve) ibadet içinde yetişip büyüyen genç, 3) Gönlü mescitlere bağlı olan kimse, 4) Allah yolunda birbirini sevip buluşmaları da, ayrılmaları da buna dayalı olan kimseler, 5) makam ve mevki sahibi ve güzel bir kadının isteğine 'Ben Allah'tan korkarım' diyerek haram (işlemeyen) erkek, 6) infak ettiğinden solundaki haberdar olmayacak derecede gizli sadaka veren adam, 7) tenhada (lisânen veya kalben) Allah Teâlâ'yı zikredip de gözü (dolup) taşan kimse" şeklinde sıralanarak, "güzel kadının" isteğine hayır diyebilen, dolayısıyla "yoldan çıkarma potansiyeli" olana kadından uzak duran erkeğin ahret günü ödüllendirileceği belirtilmektedir.

İbn Teymiyye'nin daha çok İslam hukuku üzerinden bir muhasebe yaparak yazdığı es-Siyasetu'ş-Şeriyye'de kadın-erkek ilişkileri ve kadının konumu "evlilik hakları" ekseninde değerlendirilmiştir. "Vali, bir sürü çobanı gibi, insanların çobanıdır. Bu manada olmak üzere Resulullah (s.a.v), "Hepiniz çobansınız; hepiniz güttüğünüzden (idareniz altındakilerden) sorumlusunuz. İmam, insanların çobanıdır ve güttüğünden -ra'iyyesinden- sorumludur. Kadın, kocasının evinin çobanıdır; bu itibarla, o da sorumludur." (İbn Teymiyye, 1999: 36).

Seâlibi ise kadının konumuyla ilgili olarak, "Bir gün İskender'e öğüt verme merakıyla yanaşan biri şöyle dedi: "Allah sana güç vermiş, memleketler nasip etmiş.. Kadınlarını çoğalt ki evladın çoğalsın, ünün dünyaya yayılsın, hatıran diri kalsın" İskender şöyle cevap verdi: "İnsanın yâd edilmeye layık oluşu, güzel yaşamak, iyi huylara sahip olmak ve iyi gelenekler bırakmakla mümkündür. Erkekleri yenen birine kadınlar karşısında yenilmek münasip değildir!" (Seâlibi, 1997: 66). Bu örnekte, hükümdarın canına vurgu yapılmaktadır. Yine, kadının konumu yönelik, "hükümdarların en bilgini dahi vezirsiz edemez. Kılıçların en kalitelisi bile tezyinata ve bileylenmeye muhtaçtır. Kadınların en akıllısı bile kocasız edemez" (Seâlibi, 1997: 132) şeklinde bir yaklaşım sergileyerek, bir taraftan en akıllı kadının kocasız yapamayacağını söylerken, vezirsiz bir 
hükümdarın olamayacağını da söylemekte, böylece hükümdarın yanında kendisine yer açmakta, hükümdarın yanına kendisini yakıştırmaktadır.

Vezirin konumuyla ilgili, benzer bir yaklaşım Turtuşi'de de yer alır. Turtuşi; "Ey dost! Bilmelisin ki kralların vezirlerinden istifade ettiği şeyler arasında en önemlileri iki husustur: Bir, kral bilmediği şeyleri vezirinden öğrenir ve bu sebeple gücü artar. İki; bildiği şeyleri de vezirinden tekrar öğrenir, bu sebeple bazı hususlardaki şüphesi yok olur" (Turtuşi,2011: 212). Turtûşînin Siracü'l-Mülük ${ }^{13 ' u n}$ sonuna eklediği "Dillerde Dolaşan Meşhur Sözler ve Mensur Hikmetlere Dair" bölümde ise konuyla ilgili bir başka anekdot vardır: Bir filozofa sormuşlar: Sen yakışıkı birisin, niçin çirkin bir kadınla evlendin? Filozof cevap vermiş: Şerrin en azını seçtim. Yine bir filozofa sormuşlar: Evlilik hakkında ne dersin? Bir ay lezzet, bir ömür keder ve eziyet (Turtuşi, 2011: 580) cevabını vermiş. Başka bir örnekte, İskender'e şöyle dediler: "Kadınlarını çoğaltsan iyi olur, neslin de çoğalır, şanın da ölümsüz olur." Şu cevabı verdi: "Şan ve hatırayı yaşatan güzel davranışlar ve övülesi bir sîrettir. Erkekleri mağlub etmiş birine, kadınlara yenilmek yakışmaz!" (Turtuşi, 2011: 152) ve bazı filozoflar şöyle derler: "Adaletsiz hükümdar yağmursuz bulut gibidir. Allah korkusu ve samimiyet taşımayan âlim, çorak toprağa benzer. Hatalarından dönmeyen genç, meyvesiz ağaç gibidir. Cimri zengin, anahtarsız kilit demektir. Sabır ve dirençten yoksun fakir, ışıksız kandile benzer. Utanmaz kadın, tuzsuz yemek gibidir" (Turtuşi, 2011: 152-153) yaklaşımı ve İran Kisralarından biri der ki: "Fars hükümdarları dört prensip üzerine ittifak ettiler:1) Yemek ancak iştah varken yenmeli, 2) Kadın sadece kocasına bakmalı, 3) Kral kendisine boyun eğildiği zaman faydalı olur, 4) Teba' ancak adaletle salah ve sükûnet bulur" (Turtuşi, 2011: 153) ifadeleri tespit edilmektedir. Ayrıca Turtuşi de bu konu ile ilgili pek çok örnek bulunmaktadır. Bu örneklerden, Ömer b. Hattab’a atfen, üç şey talihsizliktir: Bir komşu ki iyilik yaptığında saklar, senin bir kötülüğünü gördüğünde hemen fısıltıyla yayar. Bir kadın ki evde iken başının etini yer, evde olmadığında ne yaptığından emin olmaz. Bir hükümdar ki hoş muamele etsen seni övmez, hizmette kusur etsen seni hemen öldürür (Turtuşi, 2011: 180) şeklinde bir rivayete yer verilir.

Maverdi (2004: 260), Aristo'nun, İskender'e yazdığı mektubuna atıfla, kadın meselesine yaklaşımı hakkında ipucu verir. "Kaybettiğin şeylere fazla üzülme. Çünkü bu, kadınların ve zayıfların özelliğidir" dedi. Yine, "Ebu

13 Sirâcü'l-Mülûk, 1122'de (h.516) tamamlanan ve siyâsetnâme (nasihatnâme) türünün ilk örneklerinden olan bu eserde müellif siyaset felsefesi, siyaset ahlâkı, devlet yapısı ve kamu hukukunun temel ilkelerine dair görüşlerini altmış dört bölüm halinde kaydetmiştir (Kılıç, 2012: 431). 
Süfyan'ın oğlu Utbe, çocuklarının terbiyecisine şöyle demişti: "Ey Abdussamed çocuklarımı terbiyeye kendi nefsini terbiye etmekle başla. Çünkü onların gözleri senin gözlerine bağlıdır. Onlara göre güzel olan senin güzel gördüğün şeylerdir... Onlara Allah'ın kitabını öğret, zorlaştırma bıkarlar.. Şiirin en güzelini, sözün en şereflisini onlara anlat... Onları benimle korkut, onları benim dışımdakilerle edeplendir. Onlar için hastalığı teşhis ettikten sonra tedavi yapan şefkatli doktor gibi ol. Meliklerin hayatını onlara anlat. Kadınlarla konuşmaktan onları uzak tut. Benim tarafımdan bir mazerete asla güvenmesinler." (Maverdi, 2004: 293).Ayrıca, savaşta uyanık olma konusunda, Arapların söylediği en kati beyit şudur: -kavim o kavimdir ki savaşa çıktıkları zaman kadınlar temiz olarak gecelese bile uçkurlarını bağlarlar" (Maverdi, 2004: 402) şeklinde kadının konumuna yönelik olarak yorumlanabilecek ifadeler yer almaktadır.

Beydaba ve İbn Mukaffa', Kelile ve Dimne ${ }^{14}$ de (2003: 131), "En iyi dost, en iyi yardımcı öğüt verirken en az pohpohlayandır. İşlerin en hayırlısı, neticesi en iyi olandır. Kadınların en iyisi, kocasına muvafık davranandır. En güzel övgü, hakîkaten iyi ve kaliteli insanların dilinden dökülendir. En güzel hükümdarlık şımarıklık ve azgınlıktan uzak olan hükümdarlıktır. En güzel huy, kişiyi takvaya hazırlayan huydur. Yine, "kadın kocasıyla, çocuk ebeveyniyle, öğrenci hocasıyla, asker kumandanıyla, âbid diniyle, halk hükümdarıyla, hükümdar Allah korkusuyla, takva akılla, akıl tedbirle kıvamını bulur; bir bütün oluşturur (Beydaba; İbn Mukaffa, 2003: 254). Ayrıca "üç şey bomboştur, sıfırdır: 1) Suyu olmayan nehir yatağı, 2) Hükümdarı olmayan arazi, 3) Kocası olmayan kadın" (Beydaba; İbn Mukaffa, 2003: 271) şeklinde ifadelere rastlanmaktadır.

Siyasetname literatüründe Beydaba ve İbn Mukaffa (2003: 110); ve Turtuşi'de (2011: 347)"Bilginler derler ki üç şey vardır, ancak aptallar peşine düşer bu üç şeyin ve az kişi paçayı kurtarır getireceği tehlikelerden: hükümdara yâren olmak, sır tutacağı hususunda kadınlara güvenmek ve deneme amacıyla zehir içmek" şeklinde geçen ifadeler, kadın bağlamında dikkate değerdir.

Metindeki ele alınan örnekler Türk-İslam kültürünü temsil etmektedir, Narayana ise Hint kültürünü temsil etmektedir. Narayana'da kadın konusu önemli bir yer tutmakta, kadının toplumsal konumuna yönelik pek çok atıf bulunmaktadır.

\footnotetext{
${ }^{14}$ Kelîle ve Dimne çevirisiyle Arap edebiyatına fabl türü hikâye tarzını getiren İbnü'l-Mukaffa'ın sonraki nesiller üzerinde önemli etkileri olmuştur. Kelîle ve Dimne, İbnü’l-Mukaffa'ı üne kavuşturan en önemli eseri olup Hüsrev I. Enûşirvân zamanında tabip Berzeveyh (Berzûye) tarafından Hindistan'dan getirilip Pehlevîce'ye tercüme edilen Panchatantara'nın (beş makale/söz/nasihat/ders) Arapça'ya çevirisidir. Aslı Sanskritçe olan eser, Hint Hükümdarı Debşelim'in emriyle veziri Beydebâ tarafından kaleme alınmıştır. Hayvanların diliyle yazılmış hikâyelerden oluşan eserin adı iki çakal kardeşten (Kelîle, Dimne) gelir (Durmuş, 2000: 132-133).
} 
Narayana (2006: 5) "Ey kral! Şu altısı insana mutluluk verir: sürekli gelir, hastalıksız bir yaşam, bir dost, tatı dilli bir eş, itaatli bir oğlu ve yararlı bilgi... Çocuğuna borç bırakan bir baba, namusunu korumayan bir anne, gözü dışarıda güzel bir eş ve bilgisiz bir oğlu düşmandan farksızdır". Yine, "Yemek iyi çiğnenmeli, evlat iyi yetiştirilmelidir, kadın iyi itaat etmeli, kral içtenlikle hizmet etmelidir. İyice düşünüp konuşmalı, iyice düşünüp davranmalı. Böyle yapılırsa uzunca bir süre kötü bir sonuç doğmaz" (Narayana, 2006:15) ve bu doğrultuda, "itaatli kadın, eştir" (Narayana, 2006: 82) yaklaşımı ifade edilebilir.

Narayana için kadın, zenginlikle birlikte "sakınılması" gereken bir varlık olarak sunulmaktadır. "Bir kimse felaket zamanı için para ayırmalı, karısını zenginlik pahasına bile olsa korumalı ve kendisini de kadın ve zenginliğin her ikisinden de sakınmalıdır" (Narayana, 2006: 18) ve "uygun bir yer, uygun bir fırsat ve uygun bir âşık olmaması halinde kadınlar namuslu kalabilirler. Kadınlar her zaman vefasızdır, bunu tanrılar da çok iyi bilir; kadınlardan korunanlara ne mutlu. Kadınların hoşlanmadığı kimse yoktur, onlar hep birilerini severler, hep yeni bir erkek ararlar. Kadınlar bir kap tereyağına, erkekler ise yanan odun kömürüne benzerler; akıllı kişi asla ikisini bir araya getirmez. Ne alçakgönüllülük, ne iyi doğum yapma, ne dürüstlük, ne de utangaçlık. Kadının namusunu koruyan bir kur yapan olmamasıdır. Kadını çocukluğunda babası korur, olgunluğunda kocası, yaşlıığında oğlu korur, bir kadın asla başıboş bırakılmamalıdır" (Narayana, 2006: 32-33) ve "ne hediyeler, ne onurlandırma, ne içtenlik, ne üzerine titreme, ne silah zoru, ne de dinsel telkin kadınları zapt etmeye yarar, onları memnun etmek çok zordur. Zira ün, sevimlilik, erotik sanat bilgisi, zenginlik, gençlik gibi bir sürü değerlerle yüklü kocalarını bırakıp, karaktersiz, kötü niteliklerle yüklü başka erkeklere koşarlar" (Narayana, 2006: 76) şeklinde yer alan ifadeler ve "kadınlar, kötü erkeklerle birlikte olmak isterler, kral genellikle hak etmeyene mükafaat yağdırır, zenginlik cimriyi arar, yağmur tanrısı yağmurunu dağlara ve denizlere yağdırır" (Narayana, 2006: 86) şeklinde kadını "şeytanlaştıran" bir bağlama oturmaktadır.

Benzer biçimde, iyi kadın ve kötü kadın arasında ayrım yapılmaksızın, kadını şeytanlaştıran anlayışta "alkol, kadın, av, kumar, parayı israf etme, sert konuşma ve eziyet etme; bunlar kralların kusurları" (Narayana, 2006: 122) olarak ve "erkeklerle kıyaslandığında kadınların yemek yeme kapasiteleri iki kat, yetenekleri dört kat, enerjileri altı, tutkuları ise sekiz kattır" (Narayana, 2006:131) şeklinde ifade edilmektedir. Ayrıca Narayana'da (2006:125) "krala bir hilekâr, bir kadın ya da bir çocuk danışmanlık yapıyorsa, o kral hata fırtınasıyla savrulur ve kendini devlet işlerinden oluşan bir okyanusta bulacağı" şeklinde kadına yaklaşım ifade edilmektedir.

ÇÜiFD, 2018, cilt: 18, sayı: 2, ss. 1152-1179. 
Narayana için kadının değeri, erkeğin hoşnutluğuna bağlanmaktadır. Bu anlayış Hint kültüründe, kocasının ölümünden sonra intihar eden kadın örneğini çağrıştırmaktadır. "Kadın odur ki, ev işlerini güzel idare eder, bol bol çocuk doğurur, kadın odur ki, kocasını kendi canı gibi sever, sadece kocasına bağlı kalır. Kocası tarafından sevilmeyen kadın, kadın değildir, koca memnun olduğu zaman tüm tanrılar da kadından memnun demektir" (Narayana, 2006: 45) ve "Bir koca, hiçbir mücevheri olmasa bile bir kadının en değerli mücevheridir; her tarafını cevher süslese bile kocasız bir kadın zarafetten yoksun demektir", "kocasının ölümünde bile peşinden giden kadın insan vücudundaki kıllar kadar çok olan binlerce sene cennette kalır" (Narayana, 2006: 102-103).

Kadınlara güvensizlik ele alınmakta, "merhametli kral, açgözlü Brahman, kontrolden çıkmış kadın, kötü arkadaş, küstah hizmetçi ve umursamaz memur, nasıl nankör bir kimseden kaçınılırsa öyle kaçınılması gereken tiplerdir" (Narayana, 2006: 90) ve ölüme açılan kapılar sıralanırken, "hiçbir değeri olmayan bir işe atılma, akrabalara karşı çıkma, güçlüye meydan okuma ve genç kadınlara güven duyma" (Narayana, 2006: 84) şeklinde bu dört unsur ölüme açılan kapılar olarak tasvir edilmektedir.

Siyasetnameler yöneticilerin lider, savaşçı, hâkim, eş ve baba olarak rolleri üzerinde durmaktadır. Ellerindeki güçle ne yapabileceklerini örneklemektedir. Burada önceki bölümü de göz önüne alarak kadının erkeğin hayatında yerini kabul ederken kadının erkeği baştan çıkarabilecek kapasiteye de sahip olduğu göz önüne alınmalı şeklinde bir uyarıda bulunmaktadır. Kadının toplumdan soyutlanması ve erkek akrabalarının ki çoğunlukla babasının ve kocasının kontrolünde olması gerekliliğinin altı çizilmektedir. Burada aslında üzerinde durulmak istenen yöneticinin yönetiminin dışarıdan müdahaleye karşı korunması zorunluluğudur.

\section{c) Siyasetnamede Temkinli Yaklaşım: Dengelenen Kadın}

Siyasetnamelerde, hükümdarı merkeze alan bir anlayış bulunduğu için, her konuda hükümdarın dikkatli davranması tavsiye edilmektedir. Örneğin, devlet yönteminde danışmanlara aşırı güven bu hususlardan biridir. Bu konuyla ilişkili olarak hükümdara "öğüt veriyoruz" diye, bazı insanların halk adına isteklerde bulunduklarını, birilerini kötülediklerini belirten Abdulhamid el-Katib ${ }^{15}$

\footnotetext{
${ }^{15}$ Kısa adı Abdülhamîd el-Kâtib olan Ebu Galib Abdülhamîd b. Yahyâ b. Sa'd el-Kâtib (ö. 132/750), Arap risâle üslûbunun kurucusudur. Doğum yeri ve yılı hakkında kesin bilgi yoktur. Risâlelerinde verdiği bilgilere dayanarak İran veya Ârâmî asıllı olduğu hakkında görüşler ileri sürülmüştür. Kâtiplik sanatı konusunda ilk bilgi ve tecrübeyi, kız kardeşinin kocası ve Emevî Halifesi Hişâm b.
} 
(2007: 60) hükümdarı temkinli olmaya çağırmakta ve hükümdarın bürokratlardan ve danışmanlardan birine sınırsız ilgi göstermemesi gerektiğini hatırlatmaktadır. Ona göre (2007: 65) hükümdar, iyi bir yönetici, bürokratlarından ve danışmanlarından birinin sağduyusuna, bağlılığına ve kararlarında hep isabetli olduğuna emin olsa da, her problemin çözümünde onun fikrini almaktan sakınmalı ve bu kişiye ya da meclisindeki herhangi birine, kendisine kesinlikle ihtiyacı olduğunu, yönetimde ondan vazgeçemeyeceğini hissettirmemelidir. Böyle olursa, hükümdar, çevresindekilerin diline düşecek ciddi bir kusur işlemiş olur.

Nizamülmülk ise, bu konuda, "padişahın kadınlarının, "erkeklerin her zaman dışarıda bizzat gözleriyle gördükleri gibi hadiselere tanık olamayacakları için kötü maksatı kişilerden" veya "hâcibe ve hadımın söylediklerinden" etkilenerek emir verebileceğini ve bu emirlerin nihayetinde padişaha, memlekete, din ve devlet işlerine zarar vereceği uyarısında bulunur. Ona göre, tarihin bütün devirlerinde hükümdarın karısı hükümdara egemen olduğunda, rezalet, şer, fitne ve fesattan başka bir şey ele geçmemiştir (Nizamülmülk, 2009: 255). Bu örnekte, yönetimde söz sahibi olma konusunda, vezirin, kendine alan açtı̆̆ı görülmektedir.

Kadın konusu pek çok siyasetnamede karşımıza çıkan itidal ve ölçülü olmak konuları üzerinden ele alınır. Ebû Mansur es-Seâlibî (1997: 163), Âdâbu'l-Mulûk'ta kadınlar konusunda verdiği öğütleri politik yönü ağır basan bir hassasiyetle ele alır. Yemek-içmek ve şehvet konularında hükümdara ileri gitmemesi tavsiye edilir. Bu açıdan aşırılığa gitmenin hükümdarın "mizacını bozup, ömrünü kısaltacağı" ısrarla tekrarlanır ve tarihten örnekler verilir. Bu konuyla ilgili örneklerden Süleyman bin Abdülmelik bin Mervan, bir gün 30 tavuk, 100 yumurta yiyerek, kırbalar dolusu hurma şarabı içer. Ardından 4 cariyeyle yatınca tıkanıp kalır, ansızın nefesi tutulmuş ve ölüm kapısını çalar. Seâlibi (1997: 204-205) bu konuda hükümdara tavsiyelerini sürdürür. Bu öğütlerde, "bir hükümdar kesinlikle içki delisi olmamalı, şehvet ve eğlencesine aşırı düşkün olmamalı, çalgı ve cariyeye kendini kaptırmamalıdır. Aynı şekilde nafile ibadetlere, farz olmayan namaza ve zahitliğe de fazla meyletmemelidir, zira bu iki husustan herhangi birini yaptığı anda ordusunu kuramayacak, hükümdarlık işlerini yürütemeyecek, mallarını koruyamayacak ve memleketi fesada uğrayacaktır" diyerek her konuda dengeli, intiyatı olmayı telkin eder.

Abdülmelik'in kâtibi olan Ebü'l-Alâ Sâlim b. Abdullah'ın yanında kazandığı, birçok yerinde bulunan ve ders veren Abdülhamîd, hicrî ikinci asrın en meşhur risâle (resmî yazışma, mektup) yazarı olup klasik risâle tarzının esaslarını ve kaidelerini yeniden düzenlemiş ve onu bir sanat haline getirmiştir (Ergin, 1988: 225). 
Ayrıca, hükümdarı helak edecek kadınlar, av, içki ve kan dökme şeklinde dört unsur arasında yine kadınlar yer almakta ve dikkatli olunması istenmektedir (Seâlibi, 1997: 112-113). Seâlibi (1997: 187) hükümdarın savaş esnasında yapması gerekenlerle ilgili olarak, Mervan bin Muhammed'in üç ay boyunca hiçbir sofraya oturmayıp, hiçbir cariyeyle yatmadığını ve niçin böyle yaptığı sorulunca şu cevabı verdiğini belirtir: "Allah'a andolsun, Ebu Mücrim denen herif Horasan'ı kasıp kavurur, Nasr bin Seyyar'ı mancınıkla öldürürken oğlumdan bile emin olamam!" şeklinde alıntılar kadına karşı temkinli yaklaşımın örneğidir. Ayrıca Seâlibi (1997: 141), Halife Muktedir'in kadısı Ebû Ömer'in, davalara bakmadan önce karnını doyurup, ailesiyle bir araya geldiğini belirtmektedir. Dinini korumak, nefsinin götüreceği haramlara engel olmak, haksız karar vermesine yol açacak "güzel cariye" gibi rüşvetlere aldanmamak için böyle yapılmasının doğruluğuna işaret edilmekte ve kadının, silah ve tuzak olarak kullanılabilir düşüncesiyle intiyatlılık telkin edilmektedir. Bu bağlamda, siyasetname literatürü kadına temkinli yaklaşımın örneklerini sunmaktadır. Bu örneklerden Keykavus Kâbusnâme isimli eserinde (2008: 98-99), "imkânın varsa kadının bolluk içinde büyümüşünü al. Ama böyle bir hanımla evlenince, sakın onun malından bir şey isteme. Bir de kadının çok güzelini isteme. Çünkü güzel olanla herkes beraber olmak ister. Bir de kesinlikle çok dindar olsun. Orta yaşı ve ev işini başarabilecek kudrette olsun. Kendi kocasını sevsin. İyi geçimli, yüzü ak, namusunu koruyucu olsun... Sakın senden gösterişli ve senden büyük hanı alma. Evlendiğin hanım gözünü sende açsın, seni görsün. Onun gönlünde senin sevginden başka sevgi olmasın. Bütün erkekleri senin gibi sansın, başka erkeğe tamah etmesin. Bir de ey oğul, güngörmüş birisiyle evlenmek lazım, küçük kızlarla değil. Ya oğul... İşte böyle bir kadın bulursa evlenmekte sakın kusur etme. Sonra da onu beslemekte eksiklik gösterme. Hiçbir şekilde hanımına kıskançlık gösterme. Eğer kıskançlık göstereceksen, evlenmemek daha iyidir. Yani kıskanmak kesesini dolu gösterip, masraf kesesini boş gösterme. Yüce Allah, onu sana hoş tutasın diye vermiştir" şeklinde öğütlerini sıralamaktadır.

İmam Gazali (2014: 82-83) dünya ile kadınlar arasında bir benzerlik kurmakta, her ikisine karşı temkinli olmayı önermektedir. Ona göre, "dünya, erkekleri aldatan kötü bir kadına benzer, erkekler, onu görünce kendisine aşık olur, kadın onları evine çağırır, kendilerini aldatır ve helak eder". Kadını, bir zaaf faktörü olarak görür, Gazali'ye göre (2014: 62) idarecinin önce kendi içinde adaleti korumalıdır. Bu da, şehvetini ve kızgınlığını aklına ve dinine hâkim etmemesi, aklını ve dinini şehvet ve gazabın esiri yapmaması, hatta bunları aklın ve dinin emrine bağlamasıyla mümkün olur. 
Beydaba ve İbn Mukaffa'da (2003: 190) "insanlar belâ ile güvenilir kişi alış-verişle; kadın ve çocuklar fakirlikle; dostlar da ansızın gelen felâketlerle imtihan olur. Kaliteli, kalitesizden böyle anlarda ayrılır" ve (2003: 215) "zenginlik nimetine kavuşup azmayan, kadınlara aşırı düşkünlük gösterip sonunda rezil olmayan öyle azdır ki" şeklinde bir uyarı bulunmakta, aynı uyarı Narayana'da (2006: 52) da yer almaktadır. Bu dünyada zenginliğe göz dikmeyecek kimsenin olmadığını belirten Narayana (2006: 80), gençliğe ve başkasının karısının güzelliğine istekle bakmayacak kimsenin de olmadığını vurgulamaktadır. Benzer bir uyarıyı İbnu'l-Mukaffa'da (2004: 88- 89) yapmaktadır. Ona göre, "din konusunda işlerin en tehlikelisi, bedenin en bitiricisi, malın en telef edicisi, aklın en öldürücüsü, mürüvvetin en bozucusu, ululuk ve saygınlığın en hızlı gidericisi, kadınlara tutkun olmaktır".

Maverdi'de de temkinli yaklaşımın örnekleri bulunmaktadır. Eflatun'dan aktarılan "mal ve şehvet seni yere vurmazsa sen muzaffersin" rivayetine yer veren Maverdi (2004: 257), dil öğreniminin gerekliliğine işaret ettikten sonra, içerisinde zina, aşk, fuhuş, eğlence ve boş söz yerine güzel ahlaka götüren mısraları intiva eden hikmetli şiirlerin ezberletilmesi gerektiğini belirtmektedir (Maverdi, 2004: 289). Maverdi, hükümdarın otoritesini tehlikeye atacak altı hususu, mahrumiyet, kargaşa, nefse kapılış, sert ve kaba davranış, zaman ve budalalık şeklinde sıralamaktadır (2004: 441). Burada belirtilen bu altı noktaya, Beydaba ve İbn Mukaffa tarafından (2003: 122) da atıfta bulunulmaktadır. Nefse kapılma zafiyeti, kadınlara aşırı düşkünlük, eğlenceye, içkiye, ava ve sohbete kapılıp, kontrolü elden kaçırmak olarak tanımlanmaktadır.

Yöneticilere birer rehber hizmeti sunan siyasetnameler bu noktada aslında asli görevlerini yerine getirmektedir. Yöneticileri olası her türlü tuzağa karşı uyarmakta ve bu uyarıların içine kadınları da dâhil etmektedir. Genel olarak siyasetname yazarları yöneticileri hayatın her alanında ölçülü olmaları konusunda uyarmaktadır. Yeme, içme ve cinsellik gibi bütün fıtri intiyaçlar da buna dâhildir. $\mathrm{Bu}$ noktada kadın hayatın zevklerinden biri olarak ele alınmaktayken, hiçbir dünyevi zevkin ebedi olmadığının altını çizerek önemli uyarılarda bulunulmaktadır.

\section{SONUÇ}

Siyasetnamelerde hükümdara öğüt niteliğinde devletin yönetimi, komutanların seçimi, ordunun savaşa hazırlanması, adalet mekanizmasının işleyişi ve elçilerin görevlendirilmesi konularına yer verilirken, bu çalışma, siyasetname literatürünün öne çıkan on iki eserinden hareketle "kadının toplumsal konumunu" ortaya çıkarmayı amaçlamıştır. Çalışmanın bağlamı 
değerlendirildiğinde, "tek boyutlu”, "indirgemeci”, "ideolojik” denilebilecek bir çıkarımın, bilimsel ve akademik bakıştan uzak olacağı düşüncesinden hareketle, kadına yaklaşımda siyasetname literatürü, "iyimser", "kötümser" ve "temkinli" olmak üzere üç boyutlu bir tipleştirmeye imkân vermiştir.

Her dönemin dine, geleneklere, yerleşik düşüncelere vb. pek çok faktörle bağlantılı olarak değerlendirdiği bir konu olarak "kadının toplumsal konumu", güncel, aktüel ve sosyolojik bağlamdaki tartışmalar bağlamında ele alınmak yerine, bu çalışmada, "tarihsel ve toplumsal" arka plan, siyasetnameler üzerinden değerlendirilmeye ve analiz edilmeye çalışılmıştır. Pek çok alan, boyut, kaynak ve belge üzerinden ele alınabilecek kadın konusu, bu çalışmada, "siyasetnameler üzerinden ele alınmış, tarihsel kökleri açısından, tartışmaların süreklilik gösterdiği, koşullar, yönelimler ve talepler değişse de, kadın konusuna yaklaşımın zihinsel olarak sabiteler gösterdiği sonucuna ulaşılmıştır.

Siyasetnamelerde kadın olgusunun konu edildiği bu çalışmada, siyasetname literatüründe öne çıkan siyasetnamelerden, Nizamülmülk'ün Siyasetname; Abdulhamid el Katib'in Doğunun Hükümdarı; Ebu Mansur esSealibi'nin Hükümdarlık Sanatı; Keykavus'un Kabusname; Yusuf Has Hacib'in Kutadgu Bilig; Muhammed b. Turtuşi'nin Siracu'l-Müluk; Ebu'l Hasan Habib elMaverdi'nin Siyaset Sanatı, İmam Gazali'nin et-Tibru'I-Mesbûk fi Nasîhati'lMülûk (Yöneticilere Altın Öğütler), Nasiruddin Tusi, Ahlak-ı Nasıri; İbnu'lMukaffa, İslam Siyaset Üslubu ve İbn Teymiyye'nin Siyaset (es-Siyasetü'şŞeriyye) ve Hint kültürüne özgü Narayana'nın Hitopedaşa; eserleri çerçevesinde kadının toplumsal konumuna yönelik bir değerlendirme yapılmış ve belirttiğimiz siyasetnameler taranarak kadın meselesine yaklaşım ortaya konulmuştur.

Kadına değer veren ve iyimser yaklaşımda öne çıkan öğütler, a) Kadın, dünyanın güzelliklerinden birisidir. b) Kadın, yanında huzur bulunan bir varlıktır. c) Değerli bir nesneye sahipsen, o nesneyi hanımından sakınmamalısın. d) Kadının kocanın malında hakkı olduğu gibi, kocanın kendisiyle iyi geçim ve faydalandırma gibi kadına karşı görevleri bulunur. e) Kadınlara şehvetle değil, şefkatle bakmalısın f) Kadına arzu nesnesi gibi yaklaşmak yerine, kadına insani duygularla yaklaşılmalı şeklinde özetlenebilir.

Kadını ikincil gören yaklaşımda öğütlerdeki temalar, a) Kadını tehlikeli, güvenilmez ve düşman gibi gören bakış açısı, b) Kadınlar her anlamda yetinmeyen, kanaat etmeyen ve tatminsiz varlıklardır. Kötü tabiatlı, kanaatsiz kadından Allah'a sığınılır. c) İyi kadınlar, "itaatkâr" olarak tanımlanır, kadın dindar olmalı, Hz. Aişe'yi, Hz. Fatma'yı örnek olmalıdır ve d) Süslü taçlar 
takmak, süslenmek, kadın tabiatının özellikleri ve zaaflarıdır. e) Kadın, bedenen ve zihnen gelişmemiş olarak nitelenerek, kadını, eksik, yönlendirilebilir, zayıf varlık olarak gören bakış açısı, bununla bağlantılı olarak, f) Kadınlarla, devlet işleri istişare edilmemelidir ve üst yönetime getirilmemelidir. Siyasetnameyi yazan kişinin, çoğunlukla vezir, danışman olduğu düşünüldüğünde, kadınları dışlayan bir tavır sergilemesi manidardır.

Kadına temkinli yaklaşımdaki öğütler, a) Hükümdar yanındakilerin vazgeçilmez olduğunu hissettirmemelidir. b) Her konuda olduğu gibi, özellikle savaş esnasında kurulabilecek tuzaklara karşı yemeklere dikkat etmeli ve çevresindeki cariyelerden uzak durmalıdır. c) Eş olarak ölçülü davranmalı, evliliğini de bu çerçevede sürdürmeli, kötülük ve fitneye karşı eşinin kendisine egemen olmasına izin vermemelidir. d) Yemek-içmek ve şehvet konularında hükümdar aşırıya kaçmamalı, kendisine sunulan "güzel cariyeler" zafiyete yol açabilir. e) Hükümdar, eğlenceye düşkün olmaması gerektiği gibi, nafile ibadete ve zahitliğe de meyletmemelidir.

Kendi bağlamı içinde ve çok yönlü ele alınması gereken siyasetnamelerde kadın konusuna yönelik, Türk'ün (2012) "kadın, nesnedir" ve Ögel (2001), Kafesoğlu'nun (2011) belirttiği biçimde, "kadın, öznedir" şeklinde, tek yönlü ve uçlara savrulan bir tablonun ortaya çıktığını belirtmemiz gerekir. Kadın, "nesnedir" söylemi bildik bir cinsiyetçi söyleme kaymaktadır. Türk kültürü, kadına değer veriyor söylemini sorgulamayı gerektirecek yeterince veri bulunduğu gibi, Türk kültürü, kadına değer vermiyor diyen bir bakışın da geçerli olmadığını belirtmek gerekmektedir. Siyasetnamelerde kadın konusu, Türk'ün belirttiği biçimde, kadını nesneleştiren yaklaşım, "kötümser", kadını değerli gören "iyimser" ve devlet yönetimi konusunda, her konuda olduğu gibi, temkinli olmayı telkin eden "ihtiyatı" yaklaşım olarak üç boyutlu bir tipleştirme sunulmuştur.

\section{Kaynakça}

Abdulhamid El-Katib (2007). Doğunun Hükümdarı. (Çev. Güldane Gündüzöz, Soner Gündüzöz), İstanbul: Lacivert Yayıncılık. 
Acarlığlu, Ahmet (2018). "İlk Dönem İslâm Tarihinde Kadının Konumu", Artuklu Akademi: Mardin Artuklu Üniversitesi Ilahiyat Bilimleri Fakültesi Dergisi, Cilt: V, Sayı: 1, 115-139.

Aksu, Ali (2001). "Emevîler Döneminde Kadının Durumu", Cumhuriyet Üniversitesi Illahiyat Fakültesi Dergisi, Cilt: V, Sayı: 1, 263-279.

Albayrak, Fatma; Nilüfer Serin (2015). “Kutadgu Bilig ve Mârifetnâme'de Kadın Algısı," Uluslararası Sosyal Araştırmalar Dergisi, Cilt: 8, Sayı: 37, 16-37. Armaner, Neda (1961). "Hadîslere Göre Kadının Sosyal Durumuna Umumi Bir Bakış”, Ankara Üniversitesi Ilahiyat Fakültesi Dergisi, Cilt: IX, 131-139.

Arslan, Hammet (2014). “Budizm'de Kadının Konumu”, Dokuz Eylül Üniversitesi İlahiyat Fakültesi Dergisi, Cilt: I, Sayı: 39, 147-179.

Beydebâ; İbnü'l-Mukaffa (2003). Kelile ve Dimne. (Çeviri ve İnceleme. Said Aykut), İstanbul: Şule Yayınları.

Bilgin, Nuri (2006). Sosyal Bilimlerde İçerik Analizi Teknikler ve Örnek Çalışmalar, Ankara: Siyasal Kitabevi.

Çağrıcı, Mustafa (1996). "Gazzali".Türkiye Diyanet Vakfı İslam Ansiklopedisi, Cilt: 13, 489-505.

Çapcıoğlu, İhsan (2011). "Modernleşme Yolunda Türk Kadını: Osmanlı ve Cumhuriyet Dönemlerinde Kadının Toplumsal Statüsü”, Modernleşen Türkiye'de Din ve Toplum: Din, Bilgi ve Kültür Sosyolojisi Yazıları içinde, Ankara: Otto Yayınları, 173-194.

Debreli, Zekiye Gizem (2016). Kutadgu Bilig'de Kadın, Studies of The Ottoman Domain (Osmanlı Hâkimiyet Sahası Çalışmaları), Cilt: 6, Sayı: 11, 3860.

DiA Komisyon (2002). "Kutadgu Bilig". Türkiye Diyanet Vakfı İslam Ansiklopedisi, Cilt: 26, 478-480. 
Dönmez, Süleyman (2018). “Dede Korkut Kitabı Bağlamında Eski Türklerdeki Hanım Anlayışı", Siirt Üniversitesi Illahiyat Fakültesi Dergisi, 11-30.

Durmuş, İsmail (2000), "İbnü'l-Mukaffa'". Türkiye Diyanet Vakfı İslam Ansiklopedisi, Cilt: 21; 130-134.

Ebu Mansur Es-Seâlibî (1997). Hükümdarlık Sanatı (Âdâbu'l-Mulûk). (Çev. Sait Aykut), İstanbul: İnsan Yayınları.

Ergin, Şakir (1988). "Abdülhamîd el-Kâtib".Türkiye Diyanet Vakfı İslam Ansiklopedisi, Cilt:1;225.

Erkilet Başer, Alev (1998). "Modernleşme ve Özel Alan-Kamusal Alan Dikotomisi Açısından Müslüman Kadının Dönüşümü”, Tezkire, Sayı: 13, 71-85.

Haourani, Albert (2001). Arap Halkları Tarihi. (Çev. Yavuz Alogan), İstanbul: İletişim Yayınları.

İbn Teymiyye(1999). Siyaset (es-Siyasetü'ş-Şeriyye). (Çev. Vecdi Akyüz), İstanbul: Dergah Yayınları.

İbnu'l-Mukaffa (2004). İslam Siyaset Üslubu. (Çev. Vecdi Akyüz), İstanbul: Dergah Yayınları.

İmam Gazali(2014). et-Tibru'I-Mesbûk fi Nasîhati'l-Mülûk (Yöneticilere Altın Öğ̈̈tler). (Çev. Hüseyin Okur), İstanbul: Semerkand Yayınları.

Kafesoğlu, İbrahim (2011). Türk Millî Kültürü. Ankara: Ötüken Neşriyat.

Kallek, Cengiz (2003). "Mâverdî". Türkiye Diyanet Vakfı İslam Ansiklopedisi, Cilt: 28, 180-186.

Karasu, Teceli (2015). “Değerler ve Kadının Aile İçerisindeki Konumu”, Kadın ve Âile Sorunları Sempozyumu: Hakkari Üniversitesi Illahiyat Fakültesi, 2-3 Mayıs 2014, 268-274. 
Keykavus (2008). Kabusname. (Haz. Hasan Ahmet Gökçe), İstanbul: Lacivert Yayıncılık.

Kılıç, Muharrem (2012). "Turtuşi", Türkiye Diyanet Vakfı İslam Ansiklopedisi, Cilt: $41,430-431$.

Koca, Ferhat (1999). "İbnTeymiyye, Takıyyüddin".Türkiye Diyanet Vakfı İslam Ansiklopedisi, Cilt: 20, 391-405.

Kurtuluş, Rıza (2002). "Keykâvus b. İskender". Türkiye Diyanet Vakfı İslam Ansiklopedisi, Cilt: 25, 357.

Maverdi (2004). Siyaset Sanatı (Kitabülnasihatülmülûk). (Çev. Mustafa Sarıbıyık), İstanbul: Özgü Yayınları.

Muhammed B. Turtuşi (2011). Sirâcu'l-Müluk (Siyaset Ahlakı ve İlkelerine Dair). (Hazırlayan: Said Aykut), İstanbul: İnsan Yayınları.

Narayana (2006). Hitopedaşa (Yararlı Eğitim). (Çev. Korhan Kaya), İstanbul: Türkiye İş Bankası Kültür Yayınları.

Narlı, Nilüfer (2000). “İslam ve Türkiye'de Çağdaşlaşma Problemi ve Müslüman Toplumlarda Kadının Değişen Konumu”, Türkiye'nin Çağdaşlaşma Problemi ve İslam [Sempozyum: 3-4 Mayıs 1997, Izmir], 95-101.

Nasiruddin Tusi (2007). Ahlak-ı Nasıri. (Çev. Anar Gafarov-ZaurŞükürov), İstanbul: Litera Yayıncılık.

Nizamülmülk (2009). Siyasetname. (Çev. Mehmet Taha Ayar), İstanbul: Türkiye İş Bankası Kültür Yayınları.

Okudan, Muhammed (2013). “XIX. Yy.'da Mardin'de Aile Yapısı ve Kadının Toplumsal Statüsü”, Gaziosmanpaşa Üniversitesi Illahiyat Fakültesi Dergisi, Cilt: I, Sayı: 2, 187-200.

Ögel, Bahaeddin (2001). Dünden Bugüne Türk Kültürünün Gelişme Çağları. İstanbul: Türk Dünyası Araştırmaları Vakfı. 
Özaydın, Abdulkerim (2007). "Nizamülmülk". Türkiye Diyanet Vakfı İslam Ansiklopedisi, Cilt: 33, 194-196.

Özdeş, Talip (2009). "İslam Açısından Kadının Konumu ve Kadına Yönelik Şiddetin Değerlendirilmesi”, Eski Yeni: Üç Aylık Düşünce Dergisi, Sayı: 12, 68-76.

Sala, Bedir (2015). “Değişen Aile Yapısı ve Kadının Toplumsal Rolü”, Kadın ve Âile Sorunları Sempozyumu: Hakkari Üniversitesi Illahiyat Fakültesi, 2-3 Mayıs 2014, 374-384

Soy, Hikmet (2017). "Toplumsal Cinsiyet: Kadının Sosyal ve Hukuki Konumu”, Selçuk Üniversitesi Yayımlanmamış Yüksek Lisans Tezi.

Şirinov, Agil (2012). "Tusi, Nasiruddin". Türkiye Diyanet Vakfı İslam Ansiklopedisi, Cilt: 41, 437-442.

Teberoğlu, Haydar (2004). "İnsan Olarak Kadın, Kadının Toplumdaki Yeri ve Osmanlı'dan Kalma Önemli Bir Belge”, Türk Kültürü ve Hacı Bektaş Veli Araştırma Dergisi, Cilt: X, Sayı: 32, 55-63.

Tellioğlu, İbrahim (2016). İslam Öncesi Türk Toplumunda Kadının Konumu Üzerine, Atatürk Üniversitesi Türkiyat Araştırmaları Enstitüsü Dergisi, Sayı: 55, 209-222.

Topuzoğlu, Tevfik Rüştü (2009). "Seâlibî, Ebû Mansûr".Türkiye Diyanet Vakfı İslam Ansiklopedisi, Cilt: 36, 236-239.

Türk, H. Bahadır (2012). Çoban ve Kral Siyasetnamelerde Ideal Yönetici Imgesi. İstanbul: İletişim Yayınları.

Ünalan Turan, Sümeyra (2014). "Dindar Kadının Çalışma Hayatında Yer Almasının Dinî Anlayış ve Yaşantısı Açısından Sonuçları", Muhafazakâr Düşünce, 2014, cilt: XI, sayı: 41-42, 141-166.

Yalçın, Hatice (2016). "Alevi Kültüründe Çocuk Yetiştirme ve Kadının Konumu”, Türk Kültürü ve Hacı Bektaş Veli Araştırma Dergisi, Sayı: 79, 79-94. 
Yapıcı, Asım (2016). Toplumsal Cinsiyet Din ve Kadın, İstanbul: Çamlıca Yayınları.

Yasdıman, Hakkı Şah (2005). "Kadının İslam Geleneğindeki Yeri ve Konumuna Yahudi-Hıristiyan Kültürünün Etkilerinden Bazı Örnekler”, Süleyman Demirel Üniversitesi Illahiyat Fakültesi Dergisi, 2005/1, Sayı: 14, 59-94.

Yeter, Elife (2015). “Toplumsal Cinsiyet Bağlamında Kadının Öznelliği ve Din”, Çukurova Üniversitesi Ilahiyat Fakültesi Dergisi, Cilt: XV, Sayı: 2, 189210.

Yılmaz Anıl, Adile (2004). "Kutadgu Bilig'de Kadın”, Hacı Bektaş Veli Araştırma Dergisi, Sayı 32, 1-9.

Yusuf Has Hacib (2014). Kutadgu Bilig. İstanbul: Akvaryum Yayınevi. 


\section{Reading Women's Social Status In The Context Of The Books Of Advice: A Typological Approach}

Citation / @)- Özbolat, A. ve Çomu, A. E. (2018). Reading Women's Social Status in the Context of the Books of Advice: A Typological Approach, Cukurova University Journal of Faculty of Divinity 18 (2), 1152-1179.

Abstract- From the eighth century onward, a new literary genre emerged in the Islamized parts of the Middle East and Central Asia. The books of advice, Siyasatnamas, or Mirrors for Princes are political manuals and treatises, which constitute the main source of this paper. These handbooks provide guidance for the rulers on the subject of qualities of a good leadership and administration, and conditions and principles of monarchy. They present views on the ideal state structure and at the same time the evils caused by maladministration. The books of advice draw on existing literary works, customs, traditional rituals, and religious sources. These Works are basically compilations of stories, anecdotes and examples extracted from the Holy Quran, Hadith, pre-Islamic Persian literature and Indian fables. Having little concern with historical authenticity, these books both entertain and warn their readers with preceding incidents. The authors of the books of advice were mainly respectable and well-educated men of their era. This specific genre of didactic literature will be the main source of this study. The selected books of advice, to be addressed in this paper, are written by Yusuf Khass Hajib KaiKa'us ibn Iskandar, Nasir Ad-Din Tusi, Nizam al-Mulk, Abu Hamid al-Ghazali, Ibn Taymiyya, Abu Mansur al-Tha'alibi, Abu Bakr alTurtushi, Abu al-Hasan al-Mawardi, Abdullah ibn al-Muqaffa and Narayana. The approach to women in the books of advice will be examined in three sub-sections. The first analyzes the optimistic approach, second the pessimistic and the third one will concentrate on the cautious approach.

Keywords- Book of Advice, Administration, Status of Women, Subject, Object, Social Context. 